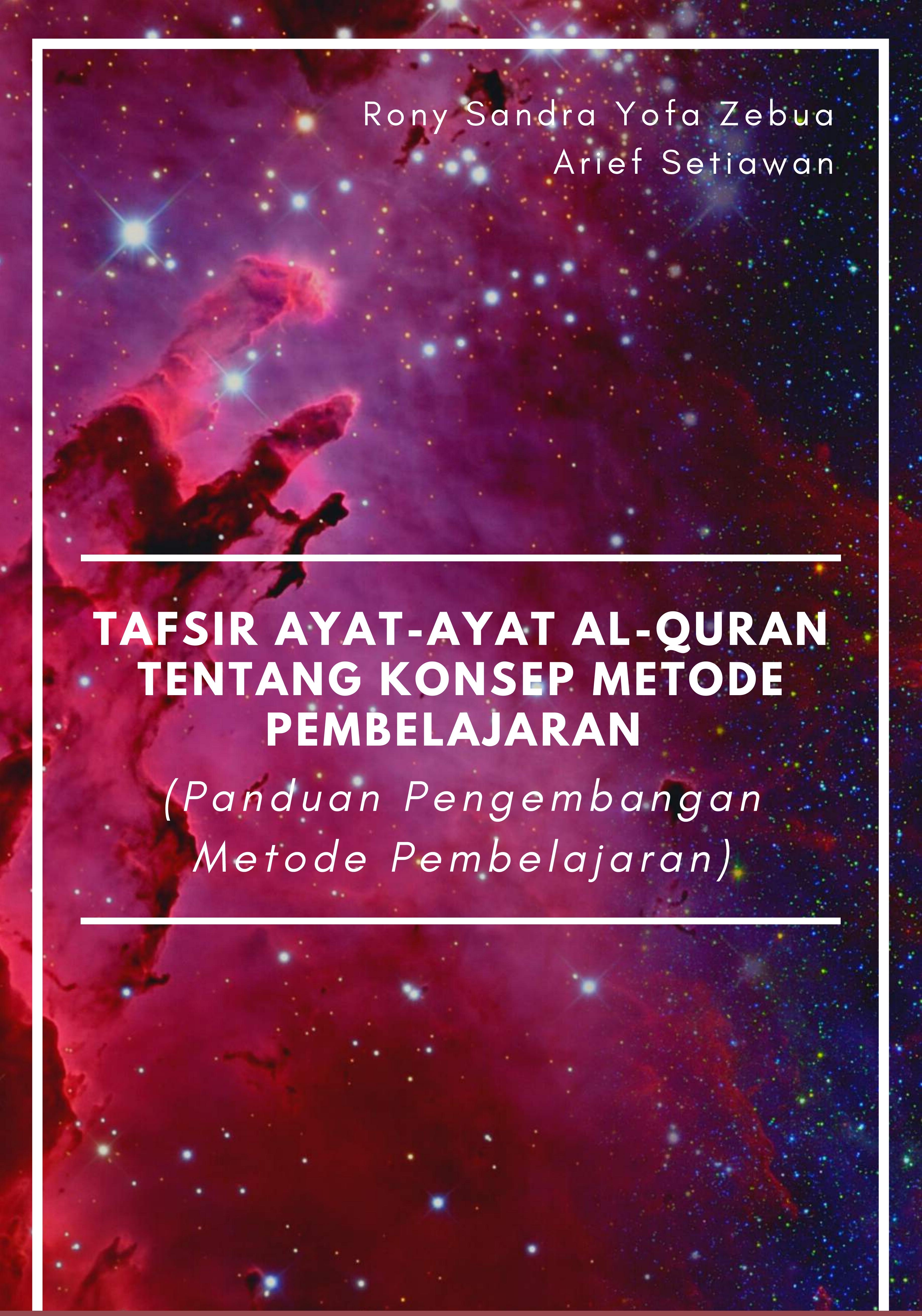

EDISI 2 


\title{
TAFSIR AYAT-AYAT AL-QURAN \\ TENTANG KONSEP METODE PEMBELAJARAN (PANDUAN PENGEMBANGAN METODE PEMBELAJARAN)
}

\author{
Rony Sandra Yofa Zebua*, Arief Setiawan* \\ * Magister Pendidikan Islam, Universitas Islam Bandung
}

\section{A. PENDAHULUAN}

Belajar merupakan kebutuhan alami yang mendasar bagi setiap manusia. Seorang manusia mulai belajar sejak ruh atau kehidupannya ditiupkan ke dalam kandungan dan kebutuhan belajar akan berhenti ketika ruh manusia tersebut telah meninggalkan jasadnya atau dengan kata lain meninggal dunia. Belajar merupakan kunci yang paling utama dalam setiap usaha pendidikan dan selalu mendapat tempat yang luas dalam berbagai disiplin ilmu, sehingga pendidikan tidak akan pernah terwujud jika tidak ada kegiatan pembelajaran (Sakilah, 2013, h. 157).

Kegiatan pembelajaran berlangsung baik secara formal di kelas maupun dalam kehidupan sehari-hari di luar kelas dan tidak selalu bersifat disengaja atau secara sadar, melainkan juga dapat sebaliknya, serta juga tidak hanya melibatkan yang benar saja, tetapi juga melibatkan yang tidak benar, karena suatu yang benar itu bisa didapat dari salah/tidak benar, seperti anak salah dalam mengeja (Mahmud, 2009 seperti dikutip dalam Irfani, 2017, h. 215). Kegiatan pembelajaran merupakan sebuah proses yang terjadi secara internal dalam diri individu dalam usaha memperoleh hubungan-hubungan baru yang dapat berupa antara perangsang-perangsang, antara reaksi-reaksi, atau antara perangsang dan reaksi (Purwanto, 2007 seperti dikutip dalam Irfani, 2017, h. 214-215).

Di dalam ajaran Islam, kegiatan pembelajaran telah dimulai sejak dalam kandungan, yang secara khusus diperkirakan sejak kandungan berumur 120 hari, karena ruh atau kehidupan seorang manusia ditiupkan pada kandungan yang telah berumur 120 hari oleh malaikat yang diperintahkan oleh Allāh subhānahu 
wa-ta'ălă. Sebagaimana ditegaskan dalam hadits shahih diantaranya Hadist Riwayat Imam Bukhari nomor 6594 dan Imam Muslim nomor 2643:

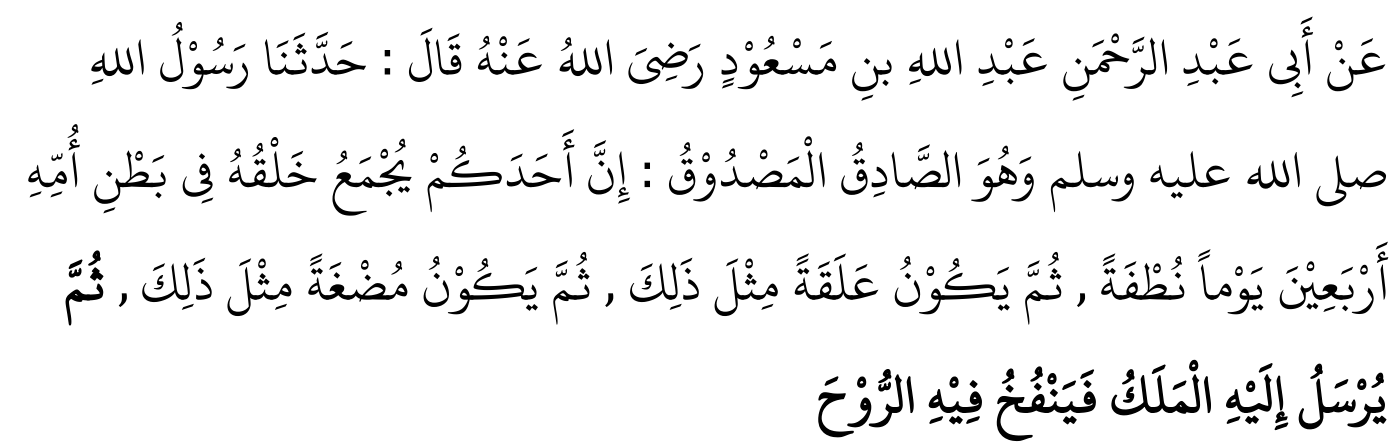

Yang terjemahannya adalah "dari Abu Abdurrahman Abdullāh bin Mas'ud radhìyallāhu 'anhu beliau berkata, Rasulullāh shallallāhu 'alaihi wa sallam menyampaikan kepada kami dan beliau adalah orang yang benar dan dibenarkan: "Sesungguhnya setiap kalian dikumpulkan penciptaannya di perut ibunya sebagai setetes mani (nuthfah) selama empat puluh hari, kemudian berubah menjadi setetes darah ('alaqah) selama empat puluh hari, kemudian menjadi segumpal daging (mudhgah) selama empat puluh hari. Kemudian diutus kepadanya seorang malaikat lalu ditiupkan padanya ruh".

\section{B. PEMBAHASAN}

Secara eksplisit maupun implisit, dalam al-Quran dan al-Hadits menggariskan bahwa metode pembelajaran setiap manusia tidak sama, terkadang manusia belajar dengan cara meniru, atau dengan cara praktis dan mencoba, atau belajar dengan cara pembiasaan dan pengkondisian, atau belajar dengan cara berpikir (Gunawan, 2014, h. 145-154). Selain itu, belajar sebaiknya dimulai dari yang paling mudah dipahami (Az-Zarnuji, 2019, h. 101).

Dengan demikian, kegiatan pembelajaran memerlukan metode yang tepat dan beragam, sehingga pembelajaran berlangsung secara lebih efektif dan efisien (Hakim, 2012, h. 8) dan tidak membosankan. Pemilihan metode pembelajaran yang digunakan dilakukan berdasarkan tujuan dan bahan pelajaran, kondisi peserta didik, kemampuan pendidik, ketersediaan media dan sumber belajar, serta kondisi lingkungan (Binti Rusli, 2019, h. 234). Dengan demikian, seyogyanya seorang pendidik yang baik akan selalu mencari sarana dan metode pendidikan yang dapat membantu peserta didik untuk mencapai potensi maksimalnya ('Ulwan, 2017, h. 515). 
Berikut beberapa ayat dalam al-Quran yang memberikan penggambaran atau arahan tentang konsep metode pembelajaran:

\section{B.1. Q.S. AL-AHZAB AYAT 21}

Q.S. Al-Ahzab ayat 21 adalah salah satu ayat yang didalamnya dapat diambil beberapa konsep metode pembelajaran. Berikut firman Allāh subhānahu wa-ta'ālā dalam surat Al-Ahzab Ayat 21:

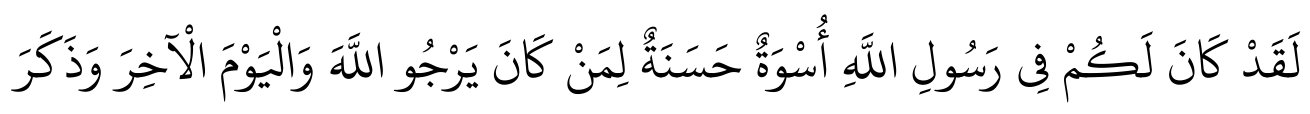

$$
\begin{aligned}
& \text { اللَََّ كَثِيرًا }
\end{aligned}
$$

Yang terjemahannya adalah "Sesungguhnya telah ada pada diri Rasulullāh itu suri teladan yang baik bagimu yaitu bagi orang yang mengharap (rahmat) Allāh dan (kedatangan) hari kiamat dan dia banyak menyebut Allāh".

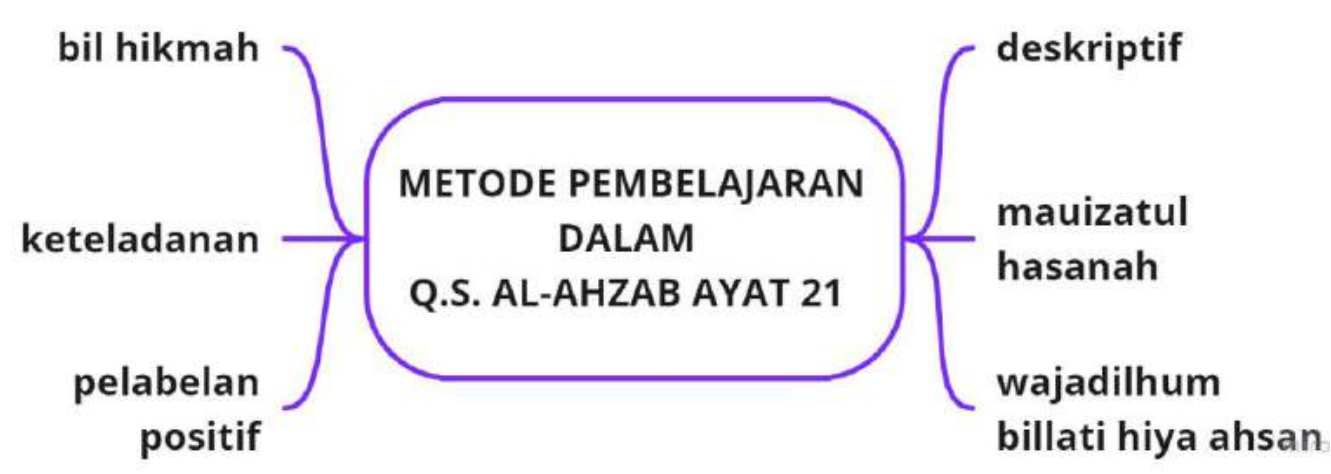

Gambar 1. Peta Analisis Metode Pembelajaran dalam Surat Al-Ahzab Ayat 21

KONSEP METODE PEMBELAJARAN YANG TERKANDUNG DALAM AL-AHZAB AYAT 21

Ada beberapa konsep metode pembelajaran di dalam surat Al-Ahzab Ayat 21, yaitu:

i) Metode bil hikmah tergambarkan maknanya dari ayat ini secara menyeluruh, di antaranya pada kalimat كَانَ لَكُمْ في رَسُولِ اللَّهِ (telah ada pada diri Rasulullāh), sebuah kalimat yang mengarahkan kepada hikmah. 
ii) Metode keteladanan yang secara khusus ditunjukkan pada dua kata kunci أُسْوَةٌ (contoh atau model) dan حَسَنَُّ (baik atau bagus), sehingga penggabungan kedua kata tersebut membentuk makna suri teladan atau contoh yang baik.

iii) Metode pelabelan positif, karena melalui dua kata kunci di atas, ayat ini mencontohkan agar memberikan label suatu karakter yang baik pada diri seseorang, sehingga menjadi stimulus untuk mewujudkan seperti apa yang dilabelkan tersebut.

iv) Metode deskriptif, karena ayat ini bersifat memberikan deskriptif atau menyampaikan sebuah informasi yang mengandung harapan agar seseorang melakukan apa yang disampaikan oleh ayat ini. Dan dalam ayat ini juga tidak terdapat kata-kata perintah.

v) Metode mauizatul hasanah, karena dalam ayat ini dapat diambil makna adanya pengajaran atau nasihat atau bimbingan yang baik, yang merupakan implikasi dari pemberian contoh atau teladan yang baik.

vi) Metode wajadilhum billati hiya ahsan atau berdiskusi dengan cara yang baik, karena secara tersirat dalam ayat ini memberikan gambaran agar melakukan diskusi dengan cara yang baik dan dengan memberikan contoh yang baik.

\section{ASBABUN NUZUL AL-AHZAB AYAT 21}

Surat Al-Ahzab merupakan surat madaniyah yang terdiri dari 73 ayat (As-Suyuthi, 2017, h. 341). Surat ini adalah surah ke-90 dari segi perurutan turunnya, yakni diturunkan sebelum surah al-Maidah dan sesudah surah AlAnfal. Ayat ini turun pada masa Perang Ahzab atau Perang Khandaq sekitar akhir tahun ke-5 Hijriyah, di mana waktu itu terdapat kaum muslimin yang mengalami takut dan guncangan saat menghadapi pasukan sekutu musuh, kemudian Allāh subhānahu wa-ta'ālā memerintahkan mereka untuk meniru kesabaran dan keteguhan Rasulullāh shallallāhu 'alaihi wa sallam (AlMubarakfuri, 2018e, h. 250-251).

\section{INTI SARI TAFSIR AL-AHZAB AYAT 21}

Ayat ini merupakan dalil yang paling kuat agar kita meneladani Rasulullāh shallallāhu 'alaihi wa sallam baik dalam perkataan maupun perbuatan dalam berbagai aktivitas keseharian (Al-Mubarakfuri, 2018e, h. 
250-251; Ishaq, 2008e, h. 328-329). Allāh subhānahu wa-ta'ālā memerintahkan manusia untuk mencontoh keteguhan, kepahlawanan, perjuangan dan kesabarannya dalam menanti pertolongan dari Rabb-nya (Ishaq, 2008e, h. 329). Perihal tersebut dicontohkan langsung oleh Rasulullāh shallallāhu 'alaihi wa sallam dalam peristiwa Al-Ahzab (Ar-Rifa'i, 2000, h. 825).

\section{URAIAN METODE PEMBELAJARAN YANG TERKANDUNG DALAM AL-AHZAB AYAT 21}

Ayat ini mengambarkan konsep tentang metode bil hikmah, metode pemberian contoh yang baik atau keteladanan, metode pelabelan positif, metode deskriptif, metode mauizatul hasanah, metode wajadilhum billati hiya ahsan.

\section{Metode bil Hikmah}

Metode bil hikmah adalah metode menyampaikan informasi atau materi dalam bentuk diksi dan komposisi yang penuh dengan kearifan, kebijaksanaan dan lemah-lembut (Nazirman, 2018, h. 37) serta selalu memperhatikan suasana (Abdullah \& Mubarak, 2019, h. 182). Hikmah secara istilah dikemukan oleh para ulama mempunyai makna yang beragam yaitu hikmah merupakan kenabian, hikmah merupakan al-Qur'an dan pemahaman terhadapnya, hikmah merupakan tepat dalam perkataan dan perbuatan, hikmah merupakan wara' atau menjauhkan diri dari perbuatan buruk, hikmah merupakan ilmu yang bermanfaat, ilmu amaliyah dan aktivitas yang membawa kepada kemashlahatan umat, hikmah merupakan sunnah Nabi, hikmah merupakan mengetahui kebenaran dan beramal dengannya, berpengetahuan yang luas dalam pembicaraan dan amal dengan berpegang teguh kepada al-Qur'an dan as-Sunnah, hikmah merupakan kondisi psikologis seperti ketundukan, kepasrahan, dan ketakutan kepada Allah, hikmah merupakan meletakan sesuatu pada tempatnya yang benar pengetahuan alda'i atau pendidik terhadap objek dakwah atau peserta didik dan memilih metode serat media yang relevan dengan mereka (Al-Qahthani, 1994 seperti dikutip dalam Nazirman, 2018, h. 32).

Metode hikmah dalam pembelajaran akan terwujud apabila memperhatikan tiga faktor utama yaitu keadaan dan situasi peserta didik, kesesuaian kadar atau ukuran materi yang disampaikan dan cara 
menyampaikan materi dengan narasi yang tepat dan tidak berlebihan. (Muhyiddin, 2002 seperti dikutip dalam Nazirman, 2018, h. 32-33).

\section{Metode Keteladanan}

Metode pemberian contoh yang baik atau teladan yang baik dilakukan oleh pendidik kepada peserta didik. Teladan yang baik menjadi sangat penting dalam proses belajar agar proses peniruan atau imitasi memberikan pengaruh positif, di mana metode ini terbukti sebagai salah satu cara yang paling efektif dan berhasil dalam mempersiapkan anak dari segi akhlak, moral dan sosialnya ('Ulwan, 2017, h. 516). Dalam ajaran Islam suri teladannya adalah Nabi Muhammad shallallāhu 'alaihi wa sallam, di mana umat Islam tidak hanya mencontoh beliau dalam hal peribadatan saja, tetapi juga dalam hal adab, akhlak, dan lainnya (Gunawan, 2014, h. 146).

Metode pembelajaran ini terealisasi ketika seseorang melakukan imitasi atau peniruan terhadap orang lain yang ada di sekelilingnya pada aspek-aspek tertentu dalam mengerjakan sesuatu maupun melafalkan suatu kata (Subri, 2014, h. 167). Oleh karena itu, menurut Zebua (2021) bahwa metode keteladanan ini membutuhkan pengkondisian lingkungan yang harus memperhatikan karakteristik dan perkembangan seseorang tersebut. Pengaruh pengkondisian lingkungan sudah terlihat pada tahap awal perkembangan seorang bayi yang masih sebatas meniru orang-orang yang berada di dekatnya, seperti apa yang dilakukan oleh ibunya (Gunawan, 2014, h. 145). Peniruan ini dilakukan dalam tahap bicara, berjalan, maupun kebiasaan-kebiasaan lainnya (Sakilah, 2013, h. 162).

Belajar dengan cara meniru ini tidak hanya ketika kecil saja, tetapi juga dilakukan oleh manusia usia dewasa yang telah memiliki tingkat perkembangan yang semakin kompleks dengan sumber belajar yang lebih luas (Gunawan, 2014, h. 145). Pada fase ini, sangat dibutuhkan strategistrategi yang tepat dan tertata dengan baik serta disesuaikan dengan perkembangan karakteristik suatu generasi, sehingga proses kegiatan transfer keteladanan berlangsung secara maksimal (Zebua \& Sunarti, 2020).

Salah satu contoh cara belajar dengan meniru yang digambarkan dalam al-Qur'an adalah pada kisah Qabil dan Habil. Setelah Habil terbunuh, Qabil tidak mengetahui bagaimana cara mengurus mayat saudaranya, kemudian Allāh mengutus burung gagak untuk menggali kuburan bagi gagak lain yang telah mati. Akhirnya Qabil meniru yang dilakukan oleh burung gagak tersebut. Kisah ini sebagaimana firman Allāh subhānahu wa-ta'ālā dalam surat Al-Maidah Ayat 31:

Google Books - http://books.google.com/books/about?id=9tA $\overline{\text { WEAAAQBAJ }-6}$ 


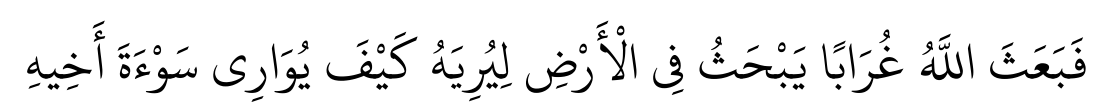

Yang terjemahannya adalah "Kemudian Allāh menyuruh seekor burung gagak menggali-gali di bumi untuk memperlihatkan kepadanya (Qabil) bagaimana seharusnya menguburkan mayat saudaranya".

\section{Metode Pelabelan Positif}

Pemberian label positif berupa karakter baik kepada peserta didik dapat memberikan stimulus bagi peserta didik untuk mewujudkan seperti apa yang dilabelkan kepadanya. Pemberian label juga dilakukan untuk menyadarkan para peserta didik tentang yang apa yang harus dipelajarinya agar menjadi sesuatu yang sesuai label tersebut (Hasanuddin, 2017, h. 307). Para pendidik memberikan pelabelan yang positif kepada peserta didik yang berprestasi agar menjadi contoh yang baik dan juga kepada peserta didik yang bermasalah agar menjadi pendorong baginya untuk berubah menjadi baik. Hal tersebut juga merupakan doa dari para pendidik dan orang-orang di sekitar untuk yang dilabelkan tersebut.

\section{Metode Deskriptif}

Metode pembelajaran deskriptif adalah metode yang memberikan informasi yang mengandung harapan agar peserta didik melakukan apa yang disampaikan tanpa adanya perintah atau paksaan untuk melakukannya. Dalam metode deskriptif terdapat informasi mengenai hasil yang akan dicapai (Darmadi, 2017, h. 3) sehingga mendorong para peserta didik untuk mencari sumber pengetahuan sebanyak-banyaknya dan diharapkan dapat mengamalkannya.

\section{Metode Mauizatul Hasanah}

Metode mauizatul hasanah merupakan salah satu manhaj atau metode dalam mendidik untuk mengajak ke jalan Allāh (Bakar, 2015, h. 60) dengan cara pengajaran atau nasihat atau bimbingan yang baik (Junaidi, 2020, h. 62) berupa tindakan mengingatkan peserta didik dengan sopan santun dan lemah lembut, sehingga dapat melunakkan hatinya kemudian tertarik dengan ajakan tersebut (Suparta \& Hifni, 2006, h. 243 seperti dikutip dalam Junaidi, 2020, h. 62). Sehingga metode mauizatul hasanah adalah untaian yang 
menyentuh hati yang membuat hati dan jiwa peserta didik terdorong melakukan kebaikan (Salim, 2010, h. 73).

Adapun bentuk-bentuk implementasi dari metode mauizatul hasanah yaitu perkataan yang jelas dan lemah lembut, isyarat yang halus dan cepat dipahami, berupa kisah-kisah dan cerita yang berkesan, pujian dan celaan, motivasi dan ancaman (Bakar, 2015).

Metode ini cocok untuk mengarahkan peserta didik yang masih kecil dan remaja, yaitu yang kapasitas pemikirannya dan intektualnya serta spritualnya masih belum berkembang sempurna serta masih ragu-ragu membedakan kebatilan atau kebenaran (Abdullah \& Mubarak, 2019, h. 182).

\section{Metode Wajadilhum Billati Hiya Ahsan}

Metode pembelajaran Wajadilhum Billati Hiya Ahsan adalah metode mendidik berupa mengajak peserta didik untuk diskusi dengan memberikan argumen yang benar dan cara yang baik (Amiruddin, 2007 seperti dikutip dalam Salim, 2010, h. 73-74). Dalam metode ini peserta didik diarahkan untuk melakukan diskusi secara berkelompok untuk membahas sebuah persoalan yang ditentukan oleh pendidik, di mana pendidik menjadi pembimbing. Dalam metode ini bisa saja terjadi perdebatan, namun pendidik memberikan batasan agar perdebatan bersifat positif dan dilakukan dengan cara yang baik.

Menurut Zakiah Daradjat (2001, hal 292 seperti dikutip dalam Izzan \& Saehudin, 2016, h. 141) metode diskusi sangat efektif untuk merangsang peserta didik dalam berpikir dan mengeluarkan pendapat sendiri, serta membangun kemampuan dalam menyelesaikan suatu persoalan tidak hanya dengan satu jawaban saja. Rasulullah mempraktekkan metode ini dalam mencari solusi dan memecahkan berbagai macam masalah yang dihadapinya secara sepakat (Izzan \& Saehudin, 2016, h. 141-142).

\section{B.2. Q.S. AL-BAQARAH AYAT 151}

Q.S. Al-Baqarah ayat 151 adalah ayat selanjutnya yang dapat diambil beberapa konsep metode pembelajaran. Berikut firman Allāh subhānahu wata'ālā dalam surat Al-Baqarah ayat 151:

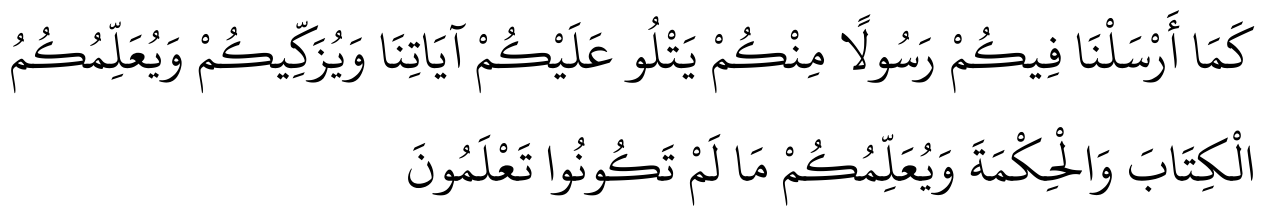

Google Books - http://books.google.com/books/about?id=9tAwEAAAQBAJ - 8 
Yang terjemahannya adalah "Sebagaimana (Kami telah menyempurnakan nikmat Kami kepadamu) Kami telah mengutus kepadamu Rasul di antara kamu yang membacakan ayat-ayat Kami kepada kamu dan mensucikan kamu dan mengajarkan kepadamu Al Kitab dan Al-Hikmah, serta mengajarkan kepada kamu apa yang belum kamu ketahui".

KONSEP METODE PEMBELAJARAN YANG TERKANDUNG DALAM ALBAQARAH AYAT 151

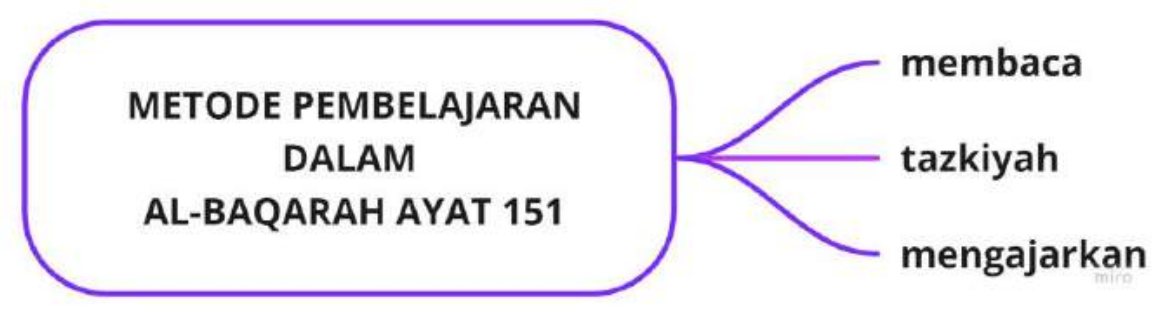

Gambar 2. Peta Analisis

Metode Pembelajaran dalam Surat Al-Baqarah ayat 151

Ada beberapa konsep metode pembelajaran di dalam surat AlBaqarah ayat 151, yaitu:

i) Metode membaca, yang secara khusus digambarkan pada kata (mengikuti atau membaca atau menceritakan) dan makna yang tepat untuk kata ini dalam ayat tersebut adalah membaca. Dan membaca yang tersirat dalam ayat ini adalah membaca ayat-ayat Allāh atau Qauliyah yang digambarkan dari kata الِْكَتابَ (al-Kitab) dan ayat-ayat dalam bentuk segala ciptaan Allāh atau Kauniyah الْحِكْمَة (al-Hikmah).

ii) Metode tazkiyah, yang secara khusus digambarkan pada kata (meningkatkan, mengembangkan, memurnikan, menyucikan), dan makna yang tepat untuk kata ini dalam ayat tersebut adalah menyucikan.

iii) Metode mengajarkan, yang secara khusus digambarkan pada kata يُعَّم (mengajarkan), yaitu memberikan pengajaran kepada yang membutuhkan ilmu dengan cara memberikan bimbingan dengan baik. 


\section{ASBABUN NUZUL AL-BAQARAH AYAT 151}

Surat Al-Baqarah merupakan surat madaniyah yang terdiri dari 286 ayat (As-Suyuthi, 2008, h. 25). Ayat ini turun setelah diturunkan surat AlBaqarah ayat 150 yang terdapat perintah Allāh subhānahu wa-ta'ālā kepada Nabi Muhammad shallallāhu 'alaihi wa sallam untuk menghadap ke arah Ka'bah ketika melaksanakan sholat, sehingga orang-orang musyrik dari penduduk Mekkah menganggap Nabi shallallāhu 'alaihi wa sallam sedang bingung (As-Suyuthi, 2017, h. 35). Sehingga surat Al-Baqarah ayat 151 ini diturunkan untuk menegaskan bahwa itu adalah perintah dari Allāh.

\section{INTI SARI TAFSIR AL-BAQARAH AYAT 151}

Allāh subḥānahu wa-ta'ālā mengingatkan hamba-Nya yang beriman terhadap nikmat yang telah dikaruniakan kepada kita berupa pengutusan Nabi Muhammad shallallāhu 'alaihi wa sallam sebagai Rasul yang membacakan ayat-ayat Allāh subhānahu wa-ta'ālā dan menyucikan kita dari berbagai keburukan akhlak, kotoran jiwa, segala perbuatan Jahiliyyah, dan mengeluarkan dari kegelapan menuju dunia yang terang benderang, mengajarkan kepada mereka al-Kitab (al-Quran) dan al-Hikmah (as-Sunah), dan mengajarkan kepada apa yang tidak kita ketahui (Al-Mubarakfuri, 2018a, h. 509; Ishaq, 2008a, h. 379). Sehingga menjadikan kita manusia yang berilmu, memiliki hati yang suci, bersahaja dan jujur dalam ucapan (Al-Mubarakfuri, 2018a, h. 509).

Kemudian Imam besar 'Abdullah bin Wahab (Ishaq, 2008a, h. 379) mengemukakan:

"Sesungguhnya Musa alaihissalam pernah bertanya: 'Ya Rabb-ku, bagaimana aku harus bersyukur kepada-Mu?' Maka Allāh Ta'ala berkata kepadanya: 'Hendaklah kamu mengingat-Ku, dan tidak melupakan-Ku. Jika kamu ingat kepada-Ku berarti kamu telah bersyukur kepada-Ku. Dan jika kamu melupakan-Ku, berarti kamu telah kufur kepada-Ku".

Selanjutnya Al-Hasan al-Bashri, Abul 'Aliyah, as-Suddi, dan Rabi' bin Anas mengatakan:

"Sesungguhnya Allāh Ta'ala akan mengingat orang yang mengingat-Nya, memberikan tambahan nikmat kepada orang yang bersyukur kepada-Nya, dan memberikan siksa kepada orang yang kufur kepada-Nya".

Google Books - http://books.google.com/books/about?id=9tAwEAAAQBAJ - 10 


\section{URAIAN METODE PEMBELAJARAN YANG TERKANDUNG DALAM AL- BAQARAH AYAT 151}

Ayat ini mengambarkan konsep tentang metode membaca, metode tazkiyah dan metode mengajarkan.

\section{Metode Membaca}

Kualitas kehidupan suatu masyarakat dapat diukur derajatnya dari aktivitas membaca, karena membaca merupakan suatu cara untuk mendapatkan informasi (Riyan, Prijana \& Sukaesih, 2015, h. 81). Metode membaca merupakan salah satu metode yang mendapatkan tempat yang penting dalam Islam. Metode ini digambarkan dalam beberapa firman Allāh subhānahu wa-ta'ālā.

Membaca merupakan kegiatan yang memiliki fungsi dan peran yang sangat penting dalam kegiatan belajar. Membaca memberikan manfaat yang sangat banyak, diantaranya adalah meningkatkan keimanan (Rachmawati, 2008 seperti dikutip dalam Meliyawati, 2016, h. 11), memperbaiki akhlak dan pembentukan fungsi-fungsi kejiwaan (purwanto, 1997 seperti dikutip dalam Meliyawati, 2016, h. 11), memberikan informasi dan memperluas pengetahuan seseorang mengenai kehidupan, meningkatkan kemampuan memahami kata dan meningkatkan kemampuan berpikir, meningkatkan kreativitas (Meliyawati, 2016, h. 11). Membaca yang paling utama dan pertama adalah membaca tentang Allāh subḥānahu wa-ta'ālā, seperti yang terdapat dalam surat Al 'Alaq ayat 1-5. Perintah membaca dalam surat Al 'Alaq ini melibatkan proses mental yang tinggi, yaitu proses pengenalan, pengingatan, pengamatan, dan daya kreasi. (Sakilah, 2013, h. 161).

\section{Metode Tazkiyah}

Pendekatan metode tazkiyah dilakukan melalui aspek kejiwaan peserta didik (Aziz, 2017, h. 304) yang berusaha membangun kesadaran internalisasi nilai (Ma'zumi, Syihabudin \& Najmudin, 2019, h. 201) atau menumbuhkan keyakinan dan keimanan (Zebua \& Suhardini, 2021). Dengan implementasi metode ini diharapkan dapat menguatkan motivasi peserta didik dalam beriman dan beramal saleh (Masyhuri, 2012, h. 95). Metode tazkiyah menurut al-Ghazali yaitu mengosongkan diri dari akhlak tercela dan mengisinya dengan akhlak terpuji, sehingga seseorang akan mudah mendekatkan diri kepada Allāh Ta'ala (Masyhuri, 2012, h. 96). Dalam konsep 
pendidikan dan pengajaran tidak saja membatasi dirinya pada proses pengetahuan sadar, akan tetapi lebih merupakan tugas untuk memberi bentuk pada tindakan hidup taat bagi individu yang melakukannya (Masyhuri, 2012, h. 97).

Metode tazkiyah merupakan metode dalam pendidikan dan dakwah yang berusaha membantu peserta didik untuk membebaskan diri dari segala perbuatan keji dan munkar sambil menghiasi diri dengan sifat-sifat terpuji sehingga terpancar pesona pribadi insan kamil (Ma'zumi dkk, 2019, h. 201). Metode ini menjadi efektif apabila dikombinasikan dengan metode keteladanan dan metode bil hikmah, serta juga harus memperhatikan prinsipprinsip yang bertahap. Metode tazkiyah dilakukan terlebih dahulu sebelum melakukan pengajaran, karena tanpa proses pensucian pada awalnya, maka tidak akan bisa mengubah keadaan peserta didik (Umar, 2012)

\section{Metode Mengajarkan}

Metode mengajarkan yaitu suatu upaya memberikan pengajaran kepada yang membutuhkan ilmu dengan cara memberikan bimbingan secara baik dan disesuaikan dengan perkembangan peserta didik. Kemudian menurut Zuhairini dkk, metode mengajar merupakan salah satu komponen dari proses pendidikan dan alat untuk mencapai tujuan, yang didukung oleh alat-alat bantu mengajar, serta bagian dari kesatuan dalam suatu sistem pendidikan (Amin, 2015, h. 1)

Metode mengajarkan sangat penting untuk dimiliki oleh seorang pendidik karena dengan metode mengajarkan yang efektif dan tepat maka pelajaran yang akan disampaikan akan berjalan secara lancar. Kelancaran proses pembelajaran tergantung bagaimana seorang pendidik menerapkan materinya kepada anak didik serta bagaimana model atau cara mamahamkan materi tersebut (Sarbani, 2015, h. 45).

\section{B.3. Q.S. AL-MAIDAH AYAT 67}

Ayat selanjutnya yang dapat digali tentang konsep metode pembelajaran adalah surat Al-Maidah ayat 67:

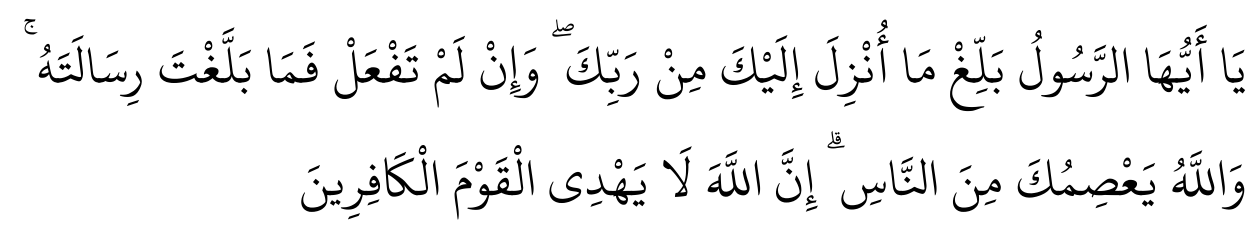

Google Books - http://books.google.com/books/about?id=9tAwEAAAQBAJ - 12 
Yang terjemahannya adalah "Hai Rasul, sampaikanlah apa yang diturunkan kepadamu dari Tuhanmu. Dan jika tidak kamu kerjakan (apa yang diperintahkan itu, berarti) kamu tidak menyampaikan amanat-Nya. Allāh memelihara kamu dari (gangguan) manusia. Sesungguhnya Allāh tidak memberi petunjuk kepada orang-orang yang kafir".

KONSEP METODE PEMBELAJARAN YANG TERKANDUNG DALAM AL-MAIDAH AYAT 67

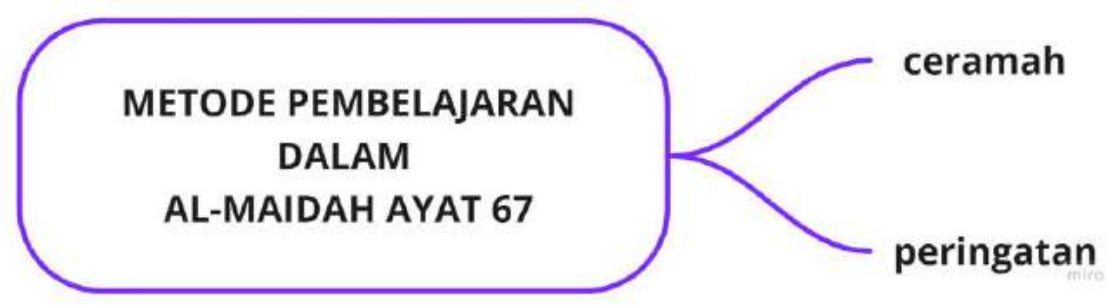

Gambar 3. Peta Analisis

Metode Pembelajaran dalam Surat Al-Maidah ayat 67

Adapun konsep metode pembelajaran di dalam surat Al-Maidah ayat 67 adalah:

i) Metode menyampaikan atau ceramah, yang secara khusus digambarkan pada kata بَلِّن (sampaikanlah, mengenai sasaran, mencapai tujuan).

ii) Metode peringatan, yang tersirat pada kalimat .... وَإِنْ لَمْ تَفْعَلْ (dan jika tidak kamu kerjakan...)

\section{ASBABUN NUZUL AL-MAIDAH AYAT 67}

Surat Al-Maidah merupakan surat madaniyah yang terdiri dari 102 ayat (As-Suyuthi, 2008, h. 212). Berdasarkan riwayat Ibnu Abi Hatim dari 'Aisyah radhìyallāhu 'anha bahwa sebelum ayat ini turun, Nabi Muhammad shallallāhu 'alaihi wa sallam dijaga oleh para sahabatnya, kemudian setelah ayat ini turun, Nabi shallallāhu 'alaihi wa sallam menyampaikan bahwa Allāh subhānahu wa-ta'ālā selalu menjaga beliau dari gangguan manusia (AlMubarakfuri, 2018c, h. 180), sehingga menimbulkan semangat dan etos 
dakwah Nabi shallallāhu 'alaihi wa sallam dalam menyampaikan risalah (AlMahalliy \& As-Suyuthi, 1990).

\section{INTI SARI TAFSIR AL-MAIDAH AYAT 67}

Allāh subḥānahu wa-ta'ālā memerintahkan kepada Rasul-Nya dan hamba-Nya untuk menyampaikan semua risalah dari Allāh dan janganlah menyembunyikan sesuatu pun termasuk alasan takut akan mendapatkan halhal yang tidak diinginkan (Al-Mubarakfuri, 2018c, h. 178). Ayat ini juga sebagai penegasan bahwa Nabi Muhammad shallallāhu 'alaihi wa sallam tidak menyembunyikan apapun dari al-Quran (Al-Mubarakfuri, 2018c, h. 178).

Arti بَلَّن menurut Imam Al-Qurtubi lebih menampakkan pada proses penyampaian amanah kepada masyarakat, karena Nabi shallallāhu 'alaihi wa sallam khawatir kepada orang-orang musyrik Mekah di awal penyebaran agama Islam, kemudian Allāh subhānahu wa-ta'ālā memerintahkan untuk menampakan kerisalahan tersebut dengan diturunkannya ayat ini dan Allāh subhānahu wa-ta'ālā memberitahu kepada Nabi bahwa Allah akan menjaga keselamatannya, Bahkan apabila Nabi shallallāhu 'alaihi wa sallam tidak menyampaikan ayat, menyembunyikan risalah dan amanat tersebut maka Nabi dikatakan sebagai orang yang "ka'dzab" atau berdusta, namun tidaklah demikian (Ishaq, 2008c, h. 154).

\section{URAIAN METODE PEMBELAJARAN YANG TERKANDUNG DALAM AL-MAIDAH AYAT 67}

Ayat ini mengambarkan konsep tentang metode ceramah dan metode peringatan.

\section{Metode Ceramah}

Metode ceramah adalah penuturan lisan secara langsung kepada peserta didik (Tambak, 2014, h. 378). Metode ceramah dilakukan dalam rangka penyampaian informasi dan motivasi secara langsung dari pendidik ke peserta didik. Metode ceramah akan berhasil apabila mendapatkan perhatian yang sungguh-sungguh dari peserta didik, disajikan secara sistematik, menggairahkan, dan memberikan kesempatan kepada peserta didik untuk 
berinteraksi (Tambak, 2014, h. 377) sebagaimana yang dilakukan oleh Nabi shallallāhu 'alaihi wa sallam.

Metode ceramah yang dicontohkan oleh Nabi shallallāhu 'alaihi wa sallam dilakukan dengan narasi yang fasih, jelas maknanya, terang, tepat dalam mengungkapkan apa yang dikehendaki, padat dan penuh makna yang dalam, di mana dengan kata lain sesuai dengan prinsip prinsip qaulan baligha atau prinsip komunikasi yang efektif (Ishaq, 2008c, h. 155). Penyampaian dalam ceramah Nabi shallallāhu 'alaihi wa sallam dilakukan dengan "bahasa" masyarakat setempat, sehingga komunikasi dalam proses pembelajaran dapat diterima peserta didik, karena komunikator menyentuh otak atau akal juga hatinya sekaligus (Ishaq, 2008c, h. 156; Al-Mahalliy \& As-Suyuthi, 1990). Dalam ceramahnya, beliau juga terkadang berhenti untuk bertanya atau memberi kesempatan yang hadir untuk bertanya, sehingga terjadilah dialog (Ishaq, 2008c, h. 156).

\section{Metode Peringatan}

Metode peringatan dilakukan oleh pendidik untuk mengingatkan peserta didik atas kesalahan atau kekhilafan yang dilakukannya (Rambe \& Samosir, 2018, h. 45). Implementasi metode ini diikuti dengan adanya ancaman atas pemberian hukuman bagi yang tetap mengabaikan peringatan tersebut ('Ulwan, 2017, h. 621). Implementasi metode ini sebaiknya diikuti dengan metode teladan, metode kisah dan metode bil hikmah serta metode motivasi.

\section{B.4. Q.S. AN-NAHL AYAT 11}

Di dalam Q.S. An-Nahl Ayat 11 juga dapat digali konsep metode pembelajaran. Berikut firman Allāh subhānahu wa-ta'ālā dalam surat An-Nahl Ayat 11:

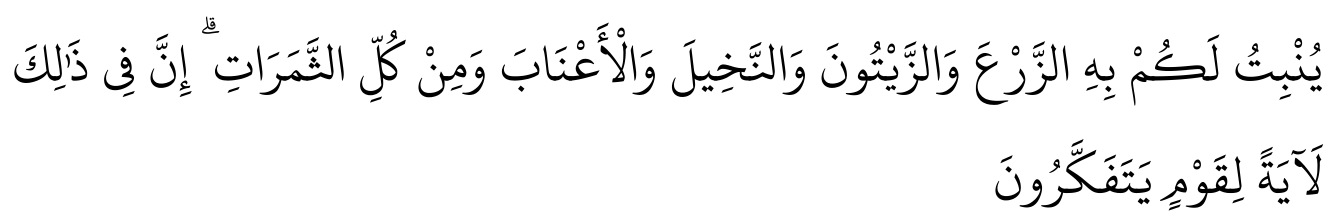

Yang terjemahannya adalah “Dia (Allāh) menumbuhkan bagi kamu dengan air hujan itu tanam-tanaman; zaitun, kurma, anggur dan segala macam buah- 
buahan. Sesungguhnya pada yang demikian itu benar-benar ada tanda (kekuasaan Allāh) bagi kaum yang memikirkan."

KONSEP METODE PEMBELAJARAN YANG TERKANDUNG DALAM AN-NAHL AYAT 11

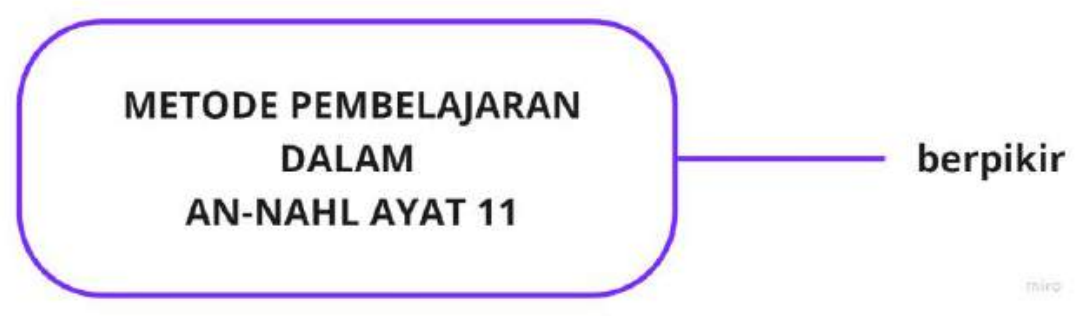

Gambar 4. Peta Analisis

Metode Pembelajaran dalam Surat An-Nahl Ayat 11

Adapun konsep metode pembelajaran di dalam An-Nahl Ayat 11 adalah metode berpikir, yang secara khusus digambarkan pada kata kunci يَتَفَكَُُْ (berpikir).

\section{ASBABUN NUZUL AN-NAHL AYAT 11}

Surat An-Nahl merupakan surat makkiyah yang terdiri dari 128 ayat (As-Suyuthi, 2008, h. 328). Tidak ada penjelasan yang dapat ditemukan dalam beberapa kitab yang menjadi penyebab turunnya ayat ini.

\section{INTI SARI TAFSIR AN-NAHL AYAT 11}

Allāh subḥānahu wa-ta'ālā menyebutkan berbagai kenikmatan yang diberikannya kepada hamba-hamba-Nya berupa turunnya hujan dari langit, yang di dalam hujan itu ada air yang dapat diminum dan menyuburkan berbagai tanaman (Ishaq, 2008d). Allāh subḥānahu wa-ta 'ālā menumbuhkan semuanya dari bumi dengan air yang sama, tetapi hasilnya berbeda jenis, rasa, warna, bau. dan bentuknya. Segala hal tersebut sesungguhnya petunjuk dan bukti yang harus kita pikirkan dan hayati sehingga menguatkan keyakinan 
kitabahwa tidak ada Tuhan selain Allāh subhānahu wa-ta'ālā (Al-Mubarakfuri, 2018d).

\section{URAIAN METODE PEMBELAJARAN YANG TERKANDUNG DALAM AN-NAHL AYAT 11}

Berpikir merupakan aktivitas belajar paling tinggi karena dengan berpikir seseorang mampu memecahkan masalahnya, menelusuri kesamaan dari perbedaan yang ada dan menarik kesimpulan dari beberapa informasi dan data yang didapat (Taufik, Shobron \& Jinan, 2016, h. 125-126). Dengan metode ini, manusia didorong untuk belajar dengan cara observasi dan pengamatan secara praktis secara terus-menerus terhadap alam semesta serta segala makhluk yang ada di dalamnya (Gunawan, 2014, h. 147). Metode berpikir termasuk tahapan selanjutnya dari metode Trial and Error dengan menambahkan kemampuan intelektual (Taufik dkk., 2016, h. 126; Gunawan, 2014, h. 147).

\section{B.5. Q.S. AN-NAHL AYAT 125}

Di dalam Q.S. An-Nahl ayat 125 juga dapat ditemukan konsep metode pembelajaran. Berikuat firman Allāh subhānahu wa-ta'ālā dalam surat AnNahl ayat 125:

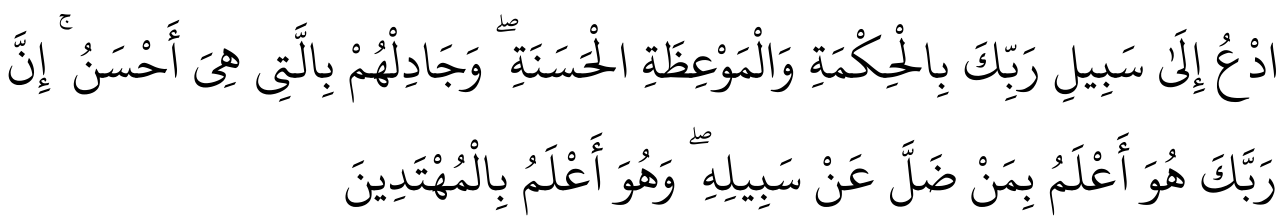

Yang terjemahannya adalah "Serulah (manusia) kepada jalan Tuhan-mu dengan hikmah dan pelajaran yang baik dan bantahlah mereka dengan cara yang baik. Sesungguhnya Tuhanmu Dia-lah yang lebih mengetahui tentang siapa yang tersesat dari jalan-Nya dan Dia-lah yang lebih mengetahui orangorang yang mendapat petunjuk.". 


\section{KONSEP METODE PEMBELAJARAN YANG TERKANDUNG DALAM AN-NAHL AYAT 125}

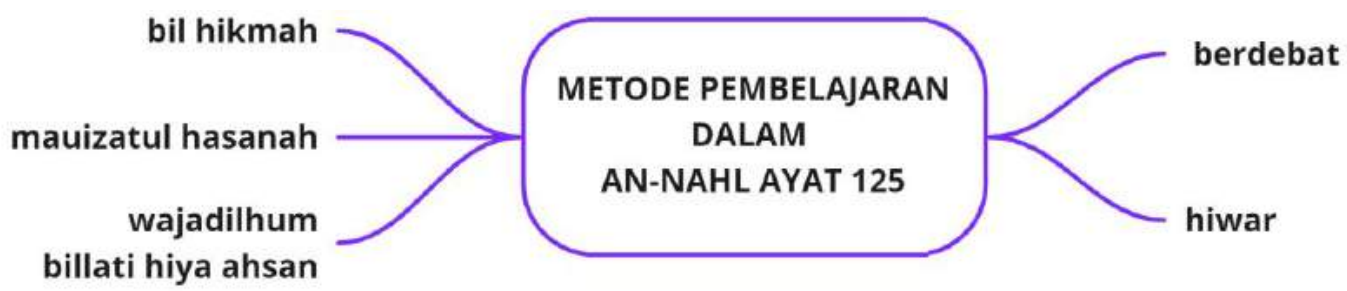

Gambar 5. Peta Analisis

Metode Pembelajaran dalam Surat An-Nahl Ayat 125

Ada beberapa konsep metode pembelajaran di dalam surat An-Nahl ayat 125 , yaitu:

i) Metode bil hikmah, yang secara khusus ditunjukkan pada kata kunci الْحِكَمَة (hikmah, kebijaksanaan).

ii) Metode mauizatul hasanah, karena dalam ayat ini dapat diambil makna tersirat adanya nasihat atau bimbingan yang baik berupa ajakan kepada dengan cara yang baik.

iii) Metode wajadilhum billati hiya ahsan atau berdiskusi dengan cara yang baik, karena secara tersirat dalam ayat ini memberikan gambaran agar melakukan dialog dan membantah (جَادِلن) dengan cara yang baik.

iv) Metode berdebat, yang secara khusus ditunjukkan pada kata kunci جَادِل (bantahlah) dengan cara yang ahsan atau baik

v) Metode hiwar atau dialog, yang secara tersirat terkandung didalam ayat ini.

\section{ASBABUN NUZUL AN-NAHL AYAT 125}

Surat An-Nahl merupakan surat makkiyah yang terdiri dari 128 ayat (As-Suyuthi, 2008, h. 328). Para mufasir berbeda pendapat seputar sebab latar belakang turunnya ayat ini. Al-Wahidi menerangkan bahwa ayat ini turun setelah Rasulullāh shallallāhu 'alaihi wa sallam menyaksikan jenazah 70 sahabat yang syahid dalam Perang Uhud, termasuk Hamzah, paman Rasulullāh shallallāhu 'alaihi wa sallam (Al-Wahidi, t.t., h. 440). Al-Qurthubi menyatakan bahwa ayat ini turun di Mekkah ketika adanya perintah kepada Rasulullāh shallallāhu 'alaihi wa sallam, untuk melakukan gencatan senjata 
dengan pihak Quraisy. Akan tetapi, Ibn Katsir tidak menjelaskan adanya riwayat yang menjadi sebab turunnya ayat tersebut (Salamah, 1420 H, h. 613).

\section{INTI SARI TAFSIR AN-NAHL AYAT 125}

Allāh subḥānahu wa-ta'ālā memerintahkan kepada Rasul-Nya, Muhammad shallallāhu 'alaihi wa sallam agar menyeru umat manusia dengan penuh hikmah dan berlemah lembut, serta bagi yang membutuhkan dialog dan tukar pikiran, maka hendaklah dilakukan dengan tutur kata yang sopan (Ishaq, 2008d, h. 256-257). Ibnu Jarir mengatakan:

\footnotetext{
"Yaitu apa yang telah diturunkan kepada beliau berupa Al-Quran dan as-Sunah serta pelajaran yang baik, yang di dalamnya berwujud larangan dan berbagai peristiwa yang disebutkan agar mereka waspada terhadap siksa Allāh Ta'ala".
}

\section{URAIAN METODE PEMBELAJARAN YANG TERKANDUNG DALAM AN-NAHL AYAT 125}

Ayat ini mengambarkan konsep tentang metode bil hikmah, mauizatul hasanah, metode wajadilhum billati hiya ahsan, metode berdebat dan metode hiwar. Pada bagian sebelumnya, penulis telah menjelaskan mengenai metode bil hikmah, mauizatul hasanah dan metode wajadilhum billati hiya ahsan. Dengan demikian, di bawah ini hanya akan dijelaskan mengenai metode berdebat dan metode hiwar.

\section{Metode Berdebat}

Metode berdebat merupakan salah satu metodologi pendidikan untuk mendapatkan hasil positif dari perbantahan argumentasi yang disampaikan oleh masing-masing pihak yang berbeda pendapat, akan tetapi hasil positif yang dicari dalam debat akan menjadi nihil apabila perdebatan tersebut dibangun di luar etika-etika yang diterapkan (Sholeh, 2016, h. 177-178).

Dalam ayat diatas, metode berdebat yang dianjurkan adalah metode berdebat yang baik dan terpuji atau jadal mamduh yaitu dengan cara yang sesuai dengan Al-Quran, yaitu didasari oleh niat yang baik, persuasi yang baik, dan hati yang lapang serta menggunakan etika-etika sopan santun yang baik (Sholeh, 2016, h. 180), sedangkan debat yang tidak baik dan harus dihindari 
adalah debat yang didasari oleh niat yang tidak baik, dengan tujuan mencari popularitas, kemenangan, memamerkan ilmu yang dimilikinya, atau debat yang tidak berdasarkan ilmu pengetahuan (Sholeh, 2016, h. 180-181).

Metode berdebat dipandang sangat cocok digunakan oleh pendidik untuk kegiatan belajar mengajar dengan materi yang ada di sekitar peserta didik dan isu masyarakat secara umum (Syathariah, 2019, h. 88). Metode ini bermanfaat untuk melatih peserta didik dalam menyampaikan argumentasinya secara ilmiah dan bagaimana cara melobi atau meyakinkan pihak lain dengan cara yang baik (Syathariah, 2019, h. 88-89). Implementasi metode debat ini seperti ini dilakukan ketika peserta didik telah memiliki kemampuan untuk berpikir secara baik dan memahami adab-adab dengan sempurna.

Metode berdebat ini juga perlu dilakukan dalam rangka membantah atau mengarahkan peserta didik yang membutuhkan bimbingan yang lebih khusus.

\section{Metode Hiwar}

Metode hiwar merupakan metode mengajar yang di dalamnya terdapat komunikasi langsung yang bersifat dua arah atau hubungan timbal balik yang terjadi secara langsung yaitu antara pendidik dengan peserta didik, yang bertujuan untuk mencapai kesimpulan atau mengambil manfaat dari pembicaraan tersebut, di mana pendidik dapat bertanya dan peserta didik menjawab atau sebaliknya (Indrawan, 2013, h.68).

Metode hiwar cocok diimplementasikan untuk pembelajaran bahasa dan juga dalam rangka mengetahui sejauh mana pemahaman peserta didik dengan melakukan tanya jawab, sebagaimana yang dipraktekkan Rasulullāh shallallāhu 'alaihi wa sallam ketika Jibril menguji beliau dengan melakukan tanya jawab (Izzan \& Saehudin, 2016, h. 134).

\section{B.6. Q.S. ALI IMRAN AYAT 104}

Ayat terakhir yang dibahas dalam artikel ini adalah Q.S. Ali Imran ayat 104, berikut firman Allāh subhāanahu wa-ta'ālā dalam surat Ali Imran ayat 104:

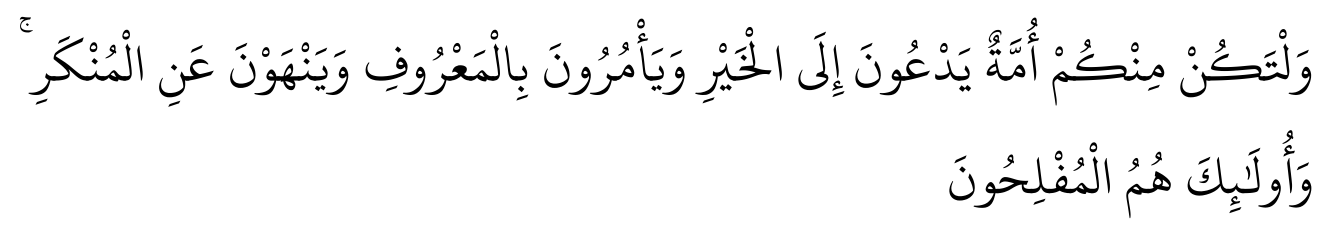

Google Books - http://books.google.com/books/about?id=9tA $\overline{\text { EAAAQBAJ }-20}$ 
Yang terjemahannya adalah "Dan hendaklah ada di antara kamu segolongan umat yang menyeru kepada kebajikan, menyuruh kepada yang ma'ruf dan mencegah dari yang munkar; merekalah orang-orang yang beruntung".

KONSEP METODE PEMBELAJARAN YANG TERKANDUNG DALAM ALI IMRAN AYAT 104

Ada beberapa konsep metode pembelajaran di dalam surat Ali Imran ayat 104, yaitu:

i) Metode amar ma'ruf nahi munkar, yang secara jelas digambarkan pada kalimat يَأْمُونَ بِالْمَعْرُوفِ وَيَنْهَوْنَ عَنِ الْمُنْكِ (mengajak kepada ma'ruf dan mencegah ke-munkar-an).

ii) Metode seruan, yang secara khusus ditunjukkan pada kata (memanggil, menyeru, mengundang).

iii) Metode larangan, yang digambarkan pada kalimat عَيْنَهَوْنَ عَنِ الْمْنْكِكِ (mencegah kemungkaran).

iv) Metode motivasi, yang secara tersirat dapat digambarkan pada kata مُفْلِحُون (orang-orang yang beruntung).

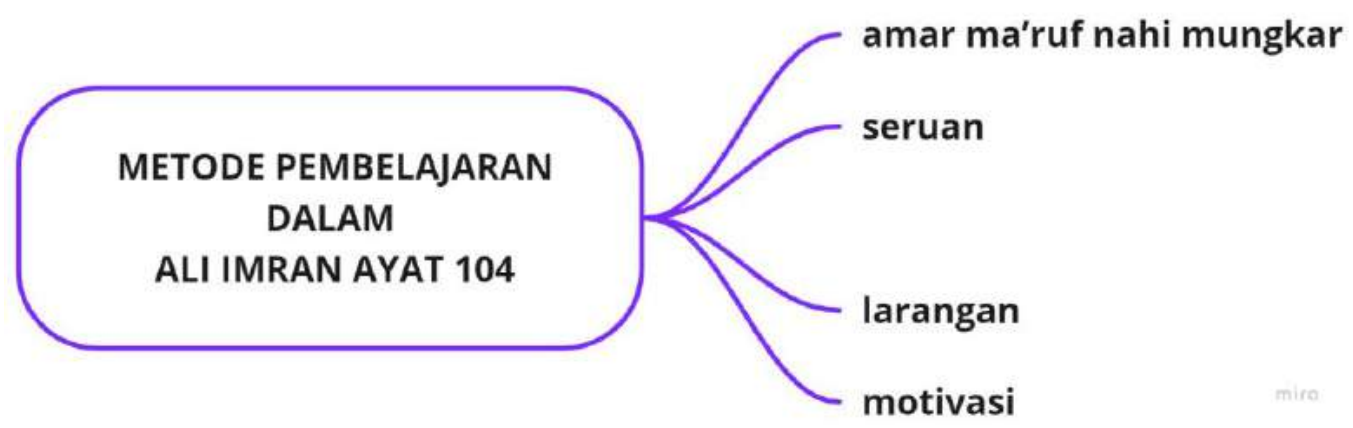

Gambar 6. Peta Analisis

Metode Pembelajaran dalam Surat Ali Imran ayat 104

\section{ASBABUN NUZUL ALI IMRAN AYAT 104}

Surat Ali Imran merupakan surat madaniyah yang terdiri dari 200 ayat (As-Suyuthi, 2008, h. 115). Pada zaman jahiliyah sebelum Islam ada dua suku yaitu; Suku Aus dan Khazraj yang selalu bermusuhan turun-temurun selama 120 tahun, permusuhan kedua suku tersebut berakhir setelah Nabi 
Muhammad shallallāhu 'alaihi wa sallam mendakwahkan Islam kepada mereka, pada akhirnya suku Aus; yakni kaum Anshar dan suku Khazraj hidup berdampingan, secara damai dan penuh keakraban.

Suatu ketika Syas Ibn Qais seorang Yahudi melihat Suku Aus dengan suku Khazraj duduk bersama dengan santai dan penuh keakraban, padahal sebelumnya mereka bermusuhan, Qais tidak suka melihat keakraban dan kedamaian mereka, lalu dia menyuruh seorang pemuda Yahudi duduk bersama suku Aus dan Khazraj untuk menyinggung perang "Bu'ast" yang pernah terjadi antara Aus dengan Khazraj. Kemudian masing-masing suku terpancing dan mengagungkan sukunya masing-masing, saling caci maki dan mengangkat senjata, dan untung Rasulullāh shallallāhu 'alaihi wa sallam yang mendengar peristiwa tersebut segera datang dan menasehati mereka: "Apakah kalian termakan fitnah jahiliyah itu, bukankah Allāh telah mengangkat derajat kamu semua dengan agama Islam, dan menghilangkan dari kalian semua yang berkaitan dengan jahiliyah?". Setelah mendengar nasehat Rasulullāh shallallāhu 'alaihi wa sallam, mereka sadar, menangis dan saling berpalukan. Sungguh peristiwa itu adalah seburuk-buruk sekaligus sebaik-baik peristiwa maka turunlah surat Ali Imran ayat 104.

\section{INTI SARI TAFSIR ALI IMRAN AYAT 104}

Allāh subḥānahu wa-ta'ālā memberikan motivasi agar ada segolongan dari umat yang memegang peran untuk mengajak atau menyeru kepada kebaikan dan melarang kepada kemungkaran sesuai dengan kapasitasnya, sebagaimana ditegaskan dalam berbagai hadits shahih Nabi shallallāhu 'alaihi wa sallam, diantaranya yang diriwayatkan Imam Ahmad dari Hudzaifah bin alYaman bahwa Nabi shallallāhu 'alaihi wa sallam bersabda (Ishaq, 2008b, h. 135-138);

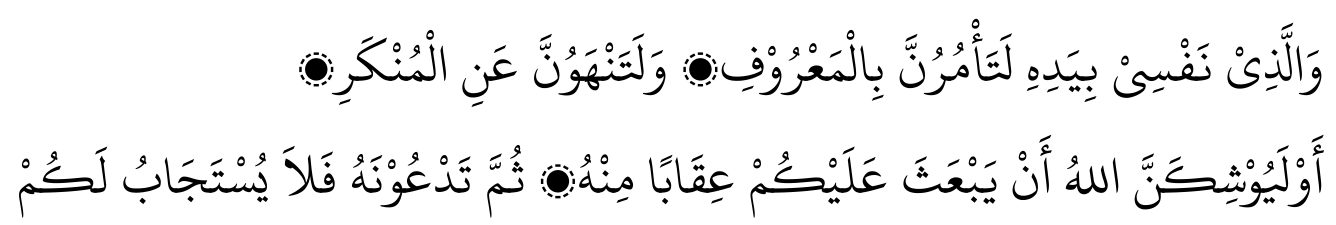

Yang terjemahannya adalah "Demi Allāh yang jiwaku berada di tangan-Nya, hendaklah kalian menyuruh kepada yang ma'ruf dan mencegah kemunkaran, atau Allāh akan menyegerakan penurunan adzab untuk kalian dari sisi-Nya, lalu klian berdoa memohon kepada-Nya dan Dia tidak mengabulkannya untuk 
kalian". (H.R. At-Tirmidzi dan Ibnu Majah. At-Tirmidzi berkata, hadits ini hasan).

URAIAN METODE PEMBELAJARAN YANG TERKANDUNG DALAM ALI IMRAN AYAT 104

Ayat ini mengambarkan konsep tentang metode amar ma'ruf nahi munkar, metode seruan, metode larangan, metode motivasi.

\section{Metode Amar Ma'ruf Nahi Munkar}

Metode Amar ma'ruf nahi munkar yaitu sebuah metode mendidik dengan mengajak kepada peserta didik untuk mengikuti dan melakukan kebaikan serta mengajak seseorang agar mereka meninggalkan dan menjauhi segala perbuatan jelek, buruk, atau jahat (Syeikh, 2018, h. 8).

Implementasi penerapan metode ini dimulai dengan mendahulukan amar ma'ruf terutama bagi peserta didik yang masih kecil atau belum baligh seperti dalam bentuk mengingatkan ketakwaan, nasihat untuk rajin beribadah, mengajak melakukan kebaikan dan adab-adab Islam ('Ulwan, 2017, h. 561). Sedangkan implementasi nahi munkar lebih tepat apabila diterapkan ketika peserta didik telah baligh. Implementasi nahi munkar harus dilakukan dengan penuh hikmah, lemah lembu, berdasarkan ilmu dan sikap wara' atau hati-hati serta tidak berlebihan (Syeikh, 2018. h. 18-19).

\section{Metode Seruan}

Metode seruan merupakan ajakan kepada keinsyafan yang berusaha mengubah situasi dari yang kurang baik menjadi situasi yang lebih baik (Ishmatulloh, 2015, h. 167), atau dengan kata lain yaitu suatu pengajaran yang menyampaikan dan memanggil serta mengajak peserta didik agar menjalankan atau mengerjakan apa yang disampaikan oleh pendidik dengan harapan agar tujuan pembelajaran bisa tercapai secara efektif dan efisien.

Dalam pelaksanaan metode ini sangat perlu digabungkan minimal dengan metode teladan, metode bil hikmah dan metode kisah, sehingga peserta didik terdorong untuk mengikuti seruan tersebut. 


\section{Metode Larangan}

Metode larangan digunakan oleh pendidik Muslim yang bertanggungjawab mengasuh seorang anak didik dengan cara bukan hanya mengajarkan kebaikan dan kebenaran tapi juga menjaga jiwa dari kesalahan (Muhidin, Ihsan, \& Syafri, 2016, h.2), jadi metode larangan digunakan agar anak didik terhindar dari kesalahan-kesalahan yang dapat membahayakan baik fisik maupun mentalnya.

Metode larangan akan menjadi efektif apabila selalu dikaitkan dengan penghargaan dan hukuman atau targhib wa tarhib yang dilakukan berdasarkan kehati-hatian yang terukur dengan baik dan adil (Fanhas \& Hamzah, 2019, h. 108). Selain itu juga diikuti oleh metode keteladanan untuk mendapatkan role model dan metode pembiasaan agar menumbuhkan kesadaran dalam diri secara seutuhnya (Fanhas \& Hamzah, 2019, h. 116).

\section{Metode Motivasi}

Metode motivasi adalah metode yang mendorong kehendak dari dalam diri yang menyebabkan seseorang melakukan suatu perbuatan (Hakim, 2012, h.26) atau suatu kondisi yang mempengaruhi seseorang untuk melakukan sesuatu sehingga mencapai tujuan tertentu.

Motivasi yang kuat dalam belajar akan mendorong seseorang untuk mencurahkan segala kemampuannya untuk kegiatan belajar (Gunawan, 2014, h. 148). Ada beberapa cara untuk membangkitkan motivasi belajar diantaranya adalah melalui at-Targhib wa at-Tarhib atau reward and punishment atau pemberian hadiah dan hukuman dan melalui cerita (Taufik dkk., 2016, h. 126-127; Subri, 2014, h. 151-152). Ayat di atas adalah salah satu contoh dari Al-Quran yang menggambarkan tentang motivasi melalui atTarghib.

\section{PETA ANALISIS}

Berdasarkan uraian diatas, maka dapat digambarkan peta analisis seperti yang ditampilkan pada Gambar 7. 


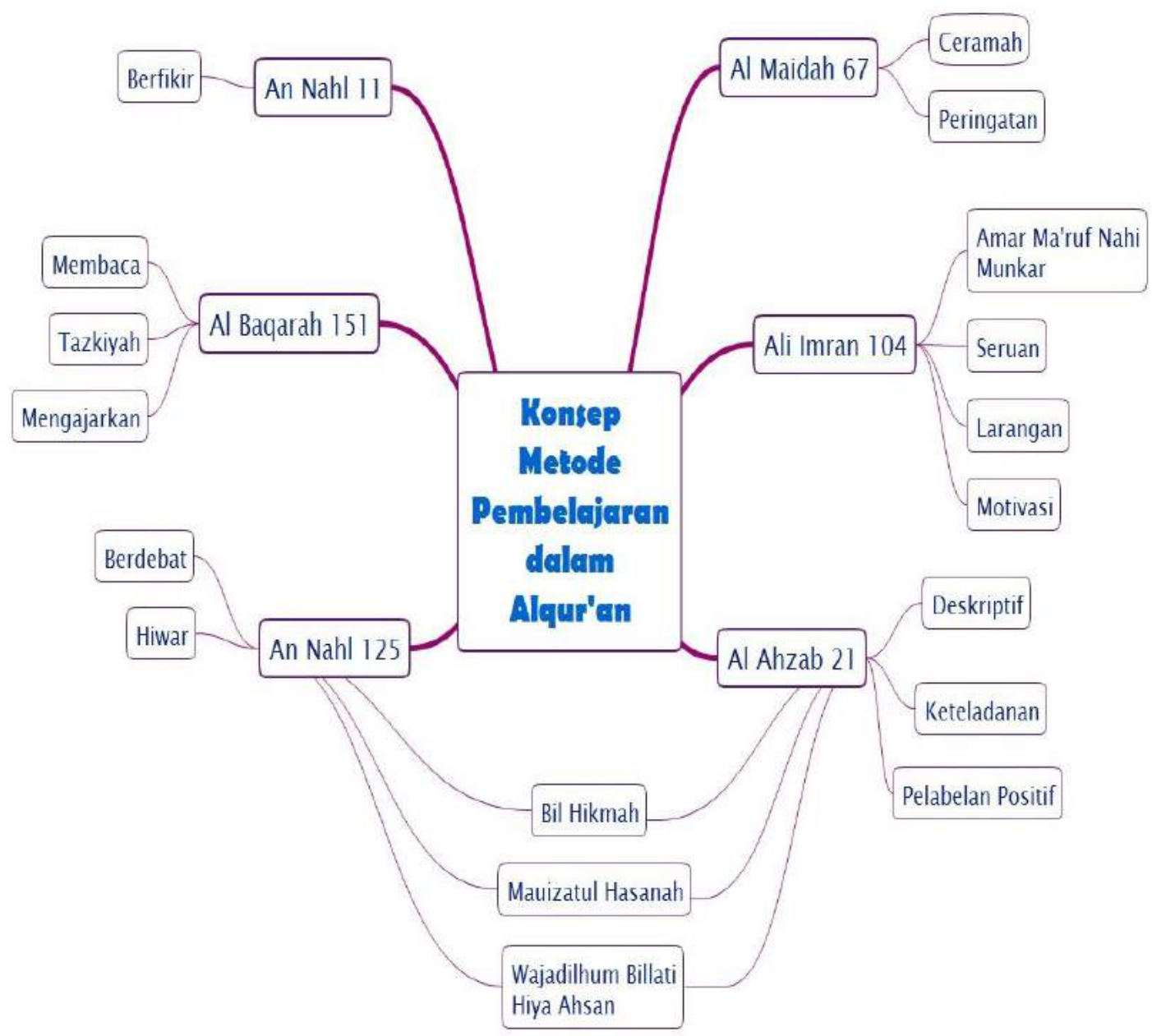

Gambar 7. Peta Analisis Konsep Metode Pembelajaran

\section{KESIMPULAN}

Tuntunan atau arahan tentang metode pembelajaran yang terdapat di dalam al-Quran baik secara eksplisit maupun implisit sangatlah lengkap apabila kita menggalinya secara terus menerus. Dari enam ayat di atas saja, kita mendapatkan banyak metode yaitu metode keteladanan, metode membaca, metode ceramah, metode mengajak berpikir atau merenungi, metode hikmah, metode pemberian motivasi dan berbagai metode lainnya. Apabila kita terus menggali dan mencari di seluruh ayat-ayat al-Quran lainnya, tentunya akan ditemukan lebih banyak lagi metode pembelajaran.

Dengan memahami dan menerapkan metode pembelajaran yang tepat, maka kegiatan belajar akan relatif lebih mudah, lebih efektif, lebih efisien dan memiliki potensi keberhasilan yang lebih besar. Oleh karena itu, para pendidik 
diharapkan untuk selalu mengembangkan diri dan menggali berbagai metode yang ada dalam al-Quran serta berusaha mengimplementasikannya semaksimal mungkin dalam kegiatan belajar mengajar.

\section{E. DAFTAR PUSTAKA}

Abdullah, M. Q. \& Mubarak, D. F. (2019). Strategi Dakwah dalam Merawat Pluralitas di Kalangan Remaja. Jurnal ANIDA: Aktualisasi Nuansa IImu Dakwah, 19(2), 177-198. doi :10.15575/anida.v19i2.7589

Al-Mahalliy, J., \& As-Suyuthi, J. (1990). Terjemah Tafsir Jalalain Berikut Asbabun Nuzul. Bandung: Sinar Baru.

Al-Mubarakfuri, S. (2018a). Shahih Tafsir Ibnu Katsir Jilid 1 (Tim Pustaka Ibnu Katsir, Penerjemah). Jakarta: Pustaka Ibnu Katsir.

Al-Mubarakfuri, S. (2018b). Shahih Tafsir Ibnu Katsir Jilid 2 (Tim Pustaka Ibnu Katsir, Penerjemah). Jakarta: Pustaka Ibnu Katsir.

Al-Mubarakfuri, S. (2018c). Shahih Tafsir Ibnu Katsir Jilid 3 (Tim Pustaka Ibnu Katsir, Penerjemah). Jakarta: Pustaka Ibnu Katsir.

Al-Mubarakfuri, S. (2018d). Shahih Tafsir Ibnu Katsir Jilid 5 (Tim Pustaka Ibnu Katsir, Penerjemah). Jakarta: Pustaka Ibnu Katsir.

Al-Mubarakfuri, S. (2018e). Shahih Tafsir Ibnu Katsir Jilid 7 (Tim Pustaka Ibnu Katsir, Penerjemah). Jakarta: Pustaka Ibnu Katsir.

Al-Wahidi. (t.t.). Al Wajid fi Tafsir Kitab Al Ajizi, Mawaqi' At-Tafasir. Mesir.

Amin, F. (2015). Metode \& Model Pembelajaran Agama Islam. Bengkulu: IAIN Bengkulu Press.

Ar-Rifa'i, M. N. (2000). Kemudahan Dari Allah: Ringkasan Tafsir Ibn Katsir (Syihabuddin, Penerjemah). Jakarta: Gema Insani Press.

As-Suyuthi. (2017). Asbabun Nuzul: Sebab-Sebab Turunnya Ayat Al-Qur'an (Ali Nurdin, Penerjemah). Jakarta: Qisthi Press

As-Suyuthi, Jalaluddin. (2008). Asbabun Nuzul: Sebab Turunnya Ayat Al-Quran (Tim Abdul Hayyie, Penerjemah). Depok: Gema Insani.

Aziz, M. A. (2017). Ilmu Dakwah. Jakarta: Kencana Prenadamedia Group

Az-Zarnuji. (2019). Ta'limul Muta'alim: Pentingnya Adab Sebelum Ilmu (Azzam, Penerjemah). Solo: Aqwam.

Bakar, A. (2015). Al-Maw'Izah Al-Hasanah (Telaah atas Metode Dakwah Dalam alQur'an Dan al-Sunnah). Jurnal DIALOGIA, 13(1), 59-71. doi: 10.21154/dialogia.v13i1.284

Binti Rusli, L. (2019). Metode Pembelajaran Dalam Al-Quran (Analisis Terhadap Ayat-Ayat Tarbawi). Jurnal INSPIRATIF PENDIDIKAN, 8(2), 231-238. doi: 10.24252/ip.v8i1.7889 
Darmadi. (2017). Pengembangan Model dan Metode Pembelajaran dalam Dinamika Belajar Siswa. Sleman: Deepublish.

Fanhas, E. \& Hamzah, N. (2019). Metode-Metode Pembelajaran Pendidikan Karakter Untuk Anak Usia Dini Menurut Q.S. Lukman: 12-19. Tasikmalaya: Edu Publisher.

Gunawan, H. (2014). Pendidikan Islam: Kajian Teoretis dan Pemikiran Tokoh. Bandung: Remaja Rosdakarya.

Hakim, T. (2012). Belajar Secara Efektif: Panduan Menemukan Teknik Belajar, Memilih Jurusan, Dan Menentukan Cita-Cita. Jakarta: Puspa Swara.

Hasanuddin. (2017). Biopsikologi Pembelajaran: Teori Dan Aplikasi. Banda Aceh: Syiah Kuala University Press.

Irfani, R. N. (2017). Konsep Teori Belajar Dalam Islam Perspektif Al-Quran Dan Hadits. Jurnal TA'DIB: Jurnal Pendidikan Islam, 6(1), 212-223. doi: 10.29313/tjpi.v6i1.2319.

Izzan, A. \& Saehudin. (2016). Hadis Pendidikan: Konsep Pendidikan Berbasis Hadis. Bandung: Humaniora.

Indrawan, I. (2013). Model Pembelajaran Nabi Muhammad SAW (Hiwar, Analogi, Tashbih dan Amtsal). Jurnal AL-AFKAR: Jurnal Keislaman dan Peradaban, 2(2). 60-119. doi: 10.28944/afkar.v1i2.43

Ishaq, A. B. M. B. A (2008a). Tafsir Ibnu Katsir Jilid 1 (A. Abdul Ghoffar EM, Penerjemah). Jakarta: Pustaka Imam Asy-Syafi'i.

Ishaq, A. B. M. B. A (2008b). Tafsir Ibnu Katsir Jilid 2 (A. Abdul Ghoffar EM, Penerjemah). Jakarta: Pustaka Imam Asy-Syafi'i.

Ishaq, A. B. M. B. A (2008c). Tafsir Ibnu Katsir Jilid 3 (A. Abdul Ghoffar EM, Penerjemah). Jakarta: Pustaka Imam Asy-Syafi'i.

Ishaq, A. B. M. B. A (2008d). Tafsir Ibnu Katsir Jilid 5 (A. Abdul Ghoffar EM, Penerjemah). Jakarta: Pustaka Imam Asy-Syafi'i.

Ishaq, A. B. M. B. A (2008e). Tafsir Ibnu Katsir Jilid 7 (A. Abdul Ghoffar EM, Penerjemah). Jakarta: Pustaka Imam Asy-Syafi'i.

Ishmatulloh, A.M. (2015). Metode Dakwah dalam Al-Quran: (Studi penafsiran Hamka terhadap QS. An-Nahl: 125). Jurnal LENTERA, 19(2). 155-169. doi: https://doi.org/10.21093/lj.v17i2.438

Junaidi. (2020). Pendekatan Komunikasi Secara Mauizatul Hasanah. Jurnal PEURAWI, 3(1), 57-69. doi: 10.22373/jp.v3i1.6720

Ma'zumi., Syihabudin. \& Najmudin. (2019). Pendidikan Dalam Al-Qur'An Dan AlSunnah: Kajian Atas Istilah Tarbiyah, Taklim, Tadris, Ta'dib dan Tazkiyah. Jurnal TARBAWY, 6(2), 193-209. doi: 10.17509/t.v6i2. 21273

Masyhuri. (2012). Prinsip-Prinsip Tazkiyah Al-Nafs Dalam Islam Dan Hubungannya Dengan Kesehatan Mental. Jurnal PEMIKIRAN ISLAM, 37(2), 95-102.

Meliyawati. (2016). Pemahaman Dasar Membaca. Yogyakarta: Deepublish. 
Muhidin, Ihsan, \& Syafri, U. A. (2016). Metode Pendidikan Akhlak dalam Kitab Adab Al-Mufrad Karya Imam Bukhari. Jurnal MISYKAT AL-ANWAR: Jurnal Kajian Islam dan Masyarakat, 27(2), 1-11. doi: 10.31904/ma.v27i2.3828

Nurdin. (2019). Implementasi Metode Pembelajaran Dalam Al-Qur'an Bagi Pendidik Era Milenial. Jurnal PIONIR: Jurnal Pendidikan, 8(1), 172-189.

Rambe, Z. \& Samosir, B. S. (2018). Penerapan Metode Pembelajaran Peringatan Dan Pemberian Motivasi Terhadap Peningkatan Minat Belajar Bidang Studi Ekonomi Pada Materi Pokok Konsumsi, Tabungan Dan Investasi Peserta Didik Kelas X Pon-Pes Muhammadiyah KH A.Dahlan Sipirok Tahun Pelajaran 20162017. Jurnal NUSANTARA, 4(1), 43-49. doi: 10.31604/jips.v4i1.2018.43-48

Riyan, A., Prijana., \& Sukaesih. (2015). POTENSI MEMBACA BUKU TEKS (Studi Pada Mahasiswa Program Studi IImu Perpustakaan Fakultas IImu Komunikasi Universitas Padjadjaran Bandung). JURNAL KAJIAN INFORMASI \& PERPUSTAKAAN, 3(1), 81-88. doi: 10.24198/jkip.v3i1.9491

Sarbani, D. A. (2015). Metode Pengajaran dalam Pendidikan Agama Islam. Jurnal AL-FATIH: Jurnal Studi Islam, 4(1), 45-54. doi: 10.22373/jiif.v11i1.66

Sakilah. (2013). Belajar dalam Perspektif Islam. Jurnal MENARA, 12(2), 156-164.

Salamah, S. B. M. (1420 H). Tafsir Al-Qur'an Al-Adzim. Madinah: Dar at-Thoyyibah Linasyri Wa Tawji'.

Salim, A. (2010). Serambi Mekkah yang Berubah. Tangerang: Pustaka Alvabet

Sholeh, M. J. (2016). Etika Berdialog dan Metodologi Debat dalam Al-Quran. Jurnal EL-FURQANIA: Jurnal Usluhuddin dan IImu-ilmu Keislaman, 2(2). 176-195.

Subri. (2014). Teori Belajar Perspektif Pendidikan Islam. JURNAL QATHRUNÂ, 1(1), 145-178.

Syathariah, S. (2019). Mari men"jadi" Guru. Sukabumi: Jejak.

Syeikh, A. K. (2018). Rekonstruksi Makna dan Metode Penerapan Amar Ma'ruf Nahi Munkar Berdasarkan Al-Quran. Jurnal AL-IDARAH: Jurnal Manajemen dan Administrasi Islam, 2(2). 1-22. doi: 10.22373/al-idarah.v2i2.4009

Tambak, S. (2014). Metode Ceramah: Konsep Dan Aplikasi Dalam Pembelajaran Pendidikan Agama Islam. JURNAL TARBIYAH, 21(2), 375-401. doi: 10.30829/tar.v21i2.16

Taufik., Shobron, S., \& Jinan, M. (2016). Islam dan Ipteks: Seri Buku Pegangan Kuliah Al-Islam dan Kemuhammadiyahan. Surakarta: Lembaga Pengembangan Al-Islam dan Kemuhammadiyahan Universitas Muhammadiyah Surakarta.

'Ulwan, A. N. (2017). Tarbiyatul Aulad fil Islam (Arif Rahman Hakim, Penerjemah). Solo: Insan Kamil.

Umar, N. (2012). Tazkiyah Pendidikan Islam. Diperoleh 6 Mei 2020, dari https://tazakka.or.id/2012/12/04/tazkiyah-pendidikan-islam/

Zebua, R. S. Y. (2021). Pendidikan Karakter Melalui Pembelajaran Daring (Sebuah Model Konseptual). Universitas Islam Bandung. Diperoleh 8 Juni 2021, dari http://books.google.com/books/about?id=6tAwEAAAQBAJ 
Zebua, R. S. Y., \& Suhardini, A. D. (2021). Model Pembelajaran Pendidikan Karakter: Panduan Operasional untuk Pembelajaran Online dan dilengkapi Contoh Implementasi pada Mapel PAI \& BP. Yogyakarta: Nas Media Pustaka. Diperoleh 8 Juni 2020, dari https://books.google.co.id/books/about/?id=SuMuEAAAQBAJ

Zebua, R. S. Y., \& Sunarti. (2020). The Strategy of Islamic Character Education with Role Model and Habituation Method on Online Learning. Ta'dib: Jurnal Pendidikan Islam, 9(2), 45-58. doi: 10.29313/tjpi.v9i2.6875 